${ }_{5 F 523}^{C}=$

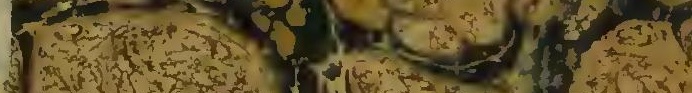

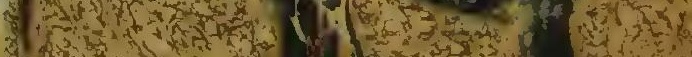

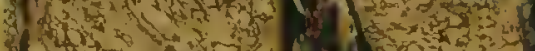
(t) $1+x$. 31 .

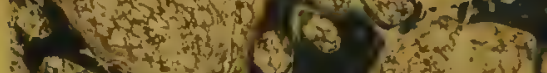
$1+30+2+20$

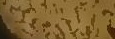

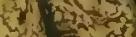
m. 3.05

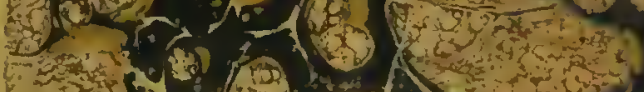
$\Rightarrow \rightarrow 1(3,5)$ (5) $(5)(1+2)$ Cor fo

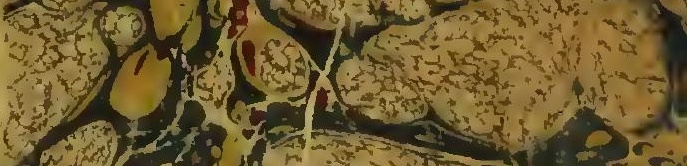

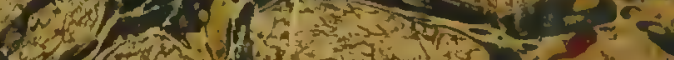
$4=12 x^{2}+x^{2}+3$

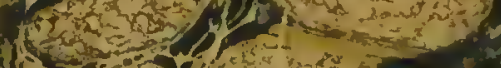
Q.

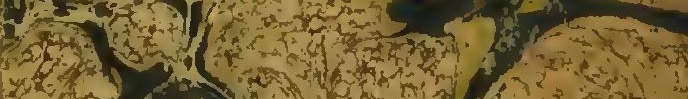

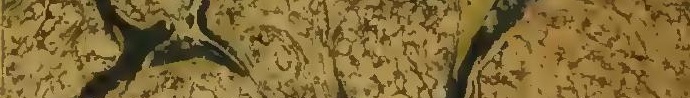
-

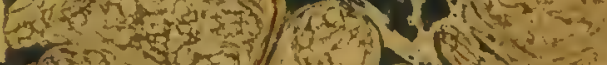

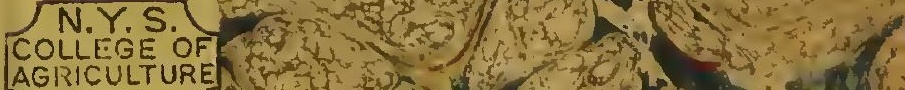

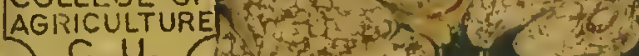



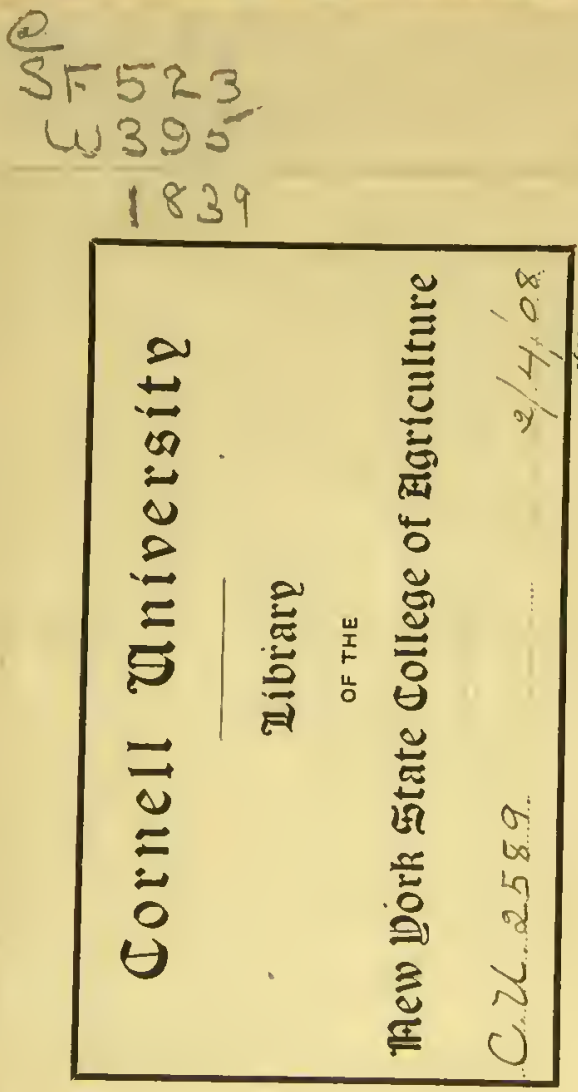

m 


a
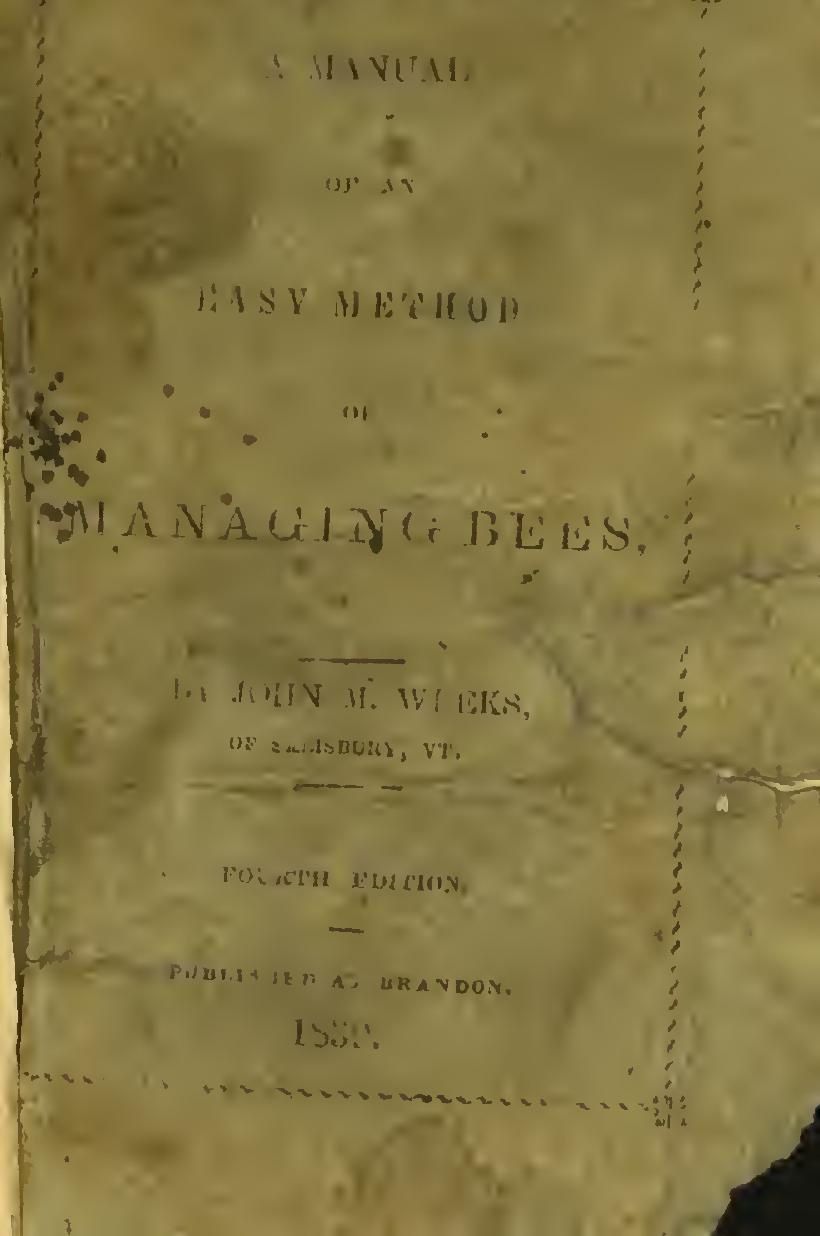


$$
-1
$$

-

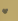

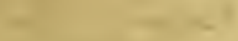
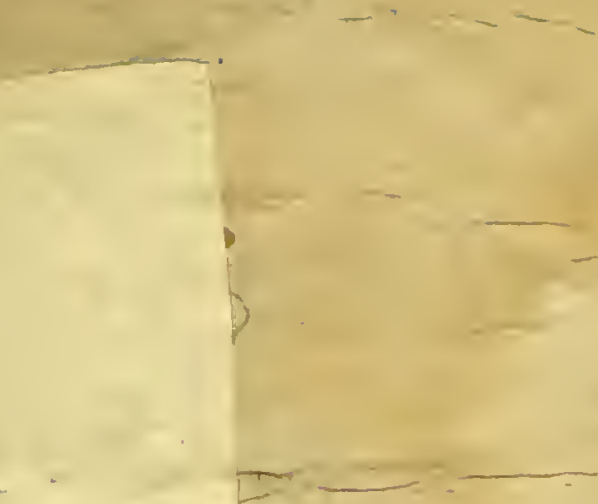

r.
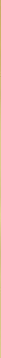



$$
\begin{aligned}
& \text { - end no. } \\
& \operatorname{lnCEE4} \\
& \text { eur. }
\end{aligned}
$$




\title{
A
}

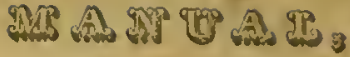

OR $\triangle N$

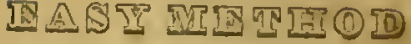

$$
\text { or }
$$

\section{MANAGING BEES,}

IN THE MOST

FROFITABLE MLANNER TO THEIR OWNER,

\author{
F.1TII
}

INFALLIBLE RULES TO PREVENT TIIEIR DESTRUCTION BY TIE MOTH.

\section{ET JOHN AI. WEEXK, \\ Of Salisbury, Vormont.}

Fourth Eticion.

BR $\$ NDON:

TERHONT TELEGRAPH OFFICE.

\section{9.}





\section{$\triangle$ MRANTEA A \\ OR $A N$ \\ E $\triangle \mathrm{S} Y$ I E T H O D \\ or}

INANAGENG HEES.

\section{RULE I.}

OF TIE CONSTRUCTION OF $\Lambda$ BEE-HIVE.

A Bec-Hive should be made of sound boards, frec from shakes and cracks : it should also be planed smooth, inside and out, made in a workmanlike manucr, and painted white on its outside. .

R E II $\Lambda \mathrm{R}$ IS $\mathrm{S}$.

That a Bee-Hive should be made perfect, so as to cxclude light and air, is obvious from the fact, that the becs will finish what tle workman has neglected, by plastering up all such cracks and crevices, or bad joints, as are left open by the joincr. The substance they use for this purpose is ncither honcy nor wax, but a kind of glue, or cement of their orrn manufacturing, and is used by the bees, to fill 
up all imperfect joints, and cxclude all light, and air. This cement, or glue, is very congenial to the growth of the MIoth, in the first stages of its existence.

The moth-miller, onter's the live, generally, in the night-malics an incision into the gluc, or cement, with her sting, and leaves her eggs deposited in the glue, where it remains secure from tlı bees; it being suarded by the timber on its sides. Thus, while a maggot, (lar$v a$ ) the moth uses the cement for food until it arrives so far towards a state of maturity as to be able to spin a web, which is more fully cxplained in remarlis on liule 10.

'The size of a hive shonld be in accordanco with the strictest rules of ceonomy, and adapted to the peculiar nature and economy of the honcy-bec, in order to mako them profitablo to their owner.

The lower apartment of the hive, where they store their fond, raise their young becs, and perform their onlinizry lithors, should hold as much as a box of thirtceu inches and onc lialf or fourtcen inches square, or ono bushel. 
Nature has fixed certain principles in the peculiar instinct of the honcy-bec, which are unaltcrablc by human wisdom.-(See General Obscrvations.)

If the hive is much larger than the one already described, the bees cannot work to advantage, and will not be likely to fill the drawcrs in several years if they sivarm, and their prosperity depends principally on swarming, for it is their nature to do so, and any managcmant which countcracts thcir natural habits, impedes them in their labors, and renders them of little profit to their owner; and they finally run out, or come to an end in a few years.

Becs in large hives never swarm ; and those in hives much loss than the one already describcd, do but little clse than raise young bees, and lay up a sufficient quantity of food to supply them through the coming winter, and are more liable to be robbed.

All hives of bees that swarm, are liable to sivarm too much, and reduce thcir colonies so low in numbers as to matcrially injure them, and is froquently the cause of their de- 
struction by the moth, which is morc particularly cxplained in renuars on liules 2 and 10.

The chamber of the hive should hold about two-thircts as mucil as the lower apartment, and be made perfectly tight, so as to excludc all light from the windors of the drawer, and also to protect them from the chilly night-air:-otherwise, the cold air of night so alters the condition of the animal heat in the crawer, that the bers arc compelled to lic in idlencss until an cquilibrium can be formed ia the box the following clay. Becs make comb in the night, and fill up the colls with honey in the day-time. . Comb is made of honey, ruminated in the stomachs of the working becs: it cxudes from the interior of its abdomen, and forms in litlle flalies betwixt its folds, and is taken by the bees in their mouth from thence, and wolded on to cnlarge the cclls and fill up their tonement with comb. Now, as it requires an cract uniformity of heat in all cascs to makic comb and chiarge the cells of a colony, itc arc able to account for the fact that becs will storc much more honcy 
in drawers than caps, which are more exposed to the cols and tiunp air of night.

Drawers should he small, like No. 2, 4, and $S$, for all purposcs cacept such as are uscd for nuliplying colouics and transferring swarms, which should always he lurge, like No. 1.

Tives should have cleats on their sides, so as to suspend them in the air, some distance from the floor of the apinry, the better to secure the becs from destruction by mice, reptiles, and oulicr vermin.

The back side, or rear of the lower apartnent of the hive, should slant forwarl so as to reuder the same smallest at the bottom, the better to sccure the combs from falling when craclicd by frost, or nearly melted in hot wcather.

No timbers or boards sheuld be placed very near the lower clyce of the hive, because it ficilitates the entrance of depredators. "That the back side should slint forward, is obvious fiom the fact, that lices generilly rest one edge of their combs on that side, and build towards the front in such a manncr as to cnter upon the same shcct where they intend to 
deposit their stores, when they first enter tho hive, without being compelled to take any unneecssary steps.

The bottom of the hive should slant downward from rear to fiont, so as to afford the greatest faeility to the bees to clear their tenement of all offensive substanees, and let the watcr, which is oceasioned by the breath and rapor of the bees, run off in cold weather.It also aids the bees vory much in preventing the entranee of robbers.

The bottom board should be suspended by staples and hooks near each comer of the hive, in such a manner as to afford a frec entrance and cgress to the bees on all its sides, which will better enable them to keep their tenement elear of the mollis.

There should be a lutton attached to the lower edge of the rear of the live, so as to cnable the apiarian to govern the bottom board in sueh a manner as to give all the air they need, or close the hive at plensure.

'The hive should have two sticls plaeed at equal distanees, cxtending from front to rear, resting on the rear, with a screw driven thro' 
the front into the end of the stick, which holds. it fast in its pluce, and a ventilator near tho top of the lower apartinent of the hive, to let off the vapor which ficquently causes the death of the bees in the winter by fieczing.

The door to the chamber should be made to fit in the rabitings of the same ngainst the jams, in such a manner as to exclude the light from the windows of the dravers, and also to prevent the entiance of the little ants. It slould also be liung by butts, or fitstened by a bar, running rertically across the centre of the door, and coufined by staples at cacli cnd. 'The under side of the eliamber flool' should bo planed smooth, then scratched with a sharp scratch, so as to raise little ridges, to cnable the becs to hold fast, otherwise they may fall suddenly upon the bottom board, which may induec them to lenve the hive and flec to the woods. 'That the inside of the hive should be made smooth is evident, from the fact that comb adheres much wore firmly to a smooth board than it does to the smalt fibres, or splirters which are left by the saw, and the comb is less likely to drop. 
Some good managers of becs, have recommended rubbing the inside of the sides of the hive with becs-twax, to enable the bees to hold first until they had sceured the comb at the top of the hive, where they always commenec their labors. The old custom of washing the hives with salt and water, swect herbs, and other substances, to give them a plcasant cfluvia, should be specdily abolished.

When bees dic, the hive should be cleared of its contents, and scraped out, and the chamber rubbed with a cloth wet in clear water, thon set in its place in the apiary, and there let it stand until wanted for usc. An old hive thus prepared, is better than a new one for the reception of a swarm of becs. The task, which is arduous and kificult in attaching the comb to the now rood, in this casc, has becn accomplished by the previous swarm.

Note-It is found by experiment that the combs in all hives, uncicr two years old, that are robbed, dic of starvation, or olherwise, may be preserved for a new swarm, which forwards the labors of a new eolony, nearly half, if the combs remain in a good state of 
prescrvation. The apiarian should examine before using, to see that the hive is clear from spiders and cobrvebs.

There should be three slicet-iron slides, which answers for a whole establishment.One of which should be nearly as wide as the chamber, and one or two inehes longer than the length of the cliamber. The other two should be the same length of the first, and half its width only.

All hives, and all their appendages, should be made cxactly of a size, and shape, in the same apiary. The trouble of equalizing colonies is far less than it is to accommodate hives to swarms. Much perplexity, and sometimes serious diffienlties occur, where the apiarian uses difforent sized hives, and dratrers. But this part of the subject will be more fully discussed under its proper rulc.

A perfect snow-white is the best color for a bec-hive. All shades of colors are conductors of hoat and cold, in proportion to thicir proxinity towards a perfect black. It is better to let the hive remain the color of the wood than paint any shade of color, which may be the 
cause of mclting the combs in summer, or freczing the becs in winter. To preserve the greatest uniformity of tempcrature in the live, both summer and winter, the apiarian will find it for his interest to make all his hives of plank at least one and a hall inch thick, or bourds threc-fourths of an inch thick, doubled in such a manner as to cxclude inscets from the joints.

\section{R U L E II.}

\section{ON SIVALALNG AND IIVING.}

The apiarian, or bec-owner, should have his hives in readiness, and in their places in the apiary, with the drawcis in their chambers, bottom up, so as to prevent cntrance.

When a swarm comes forth, and lias alighted, cut off the limb, if convenient, (unless the hiver is used) - shalic it gently, so as to disengage the becs, and let them lall gently on to the table, board or ground, (as the case may be, - place the hive over them before many rise into the air, taking carc at the same time to lay one or more sticks in sucli a manner as to raise the live so as to give the bees rapid ingress and egress. If the bces act reluctant- 
ly in taking possession of their new habitation, disturb them by brushing them with a goosequill or some other instrument not harsh, and they will soon enter. In case it is found necessary to invert the hive to receive the bees, (which is frequent from their manner of alighting,) then first secure the drawers down to the floor, by inserting a handkerchief or something above them: now invert the hive and shake or brush the bees into it: now turn it gently right end up on the table, or other place, obsorving the rule aforesaid.

\section{RE H A II S .}

Bces swarm from 9 o'clock in the morning to 3 o'clock in the afternoon on a fair day, difing in the scason according to the climatc. In Vermont, they generally stvarm from the middle of May to the 15th of July: in late scasons some later. I have known them to swarm as early as 7 in the morning, and as late as 4 in the afternoon. I have also known them to come forth when it rained so hard as nearly to defeat then by beating down many to the ground which were probably lost from their colony; and I once liad a swarm come fortl on the 16ib day of August.

Two reasons, and tro only can be assign- 
ed for the swarming of becs. The first is want of room, and the second, to avoid the conflict of the Qucens. It may be possible that a swarm may come forth before the hive is full of conb, but from more than forty years observation, I liave ncrer secn an instance of it, when the live was not full of bees at the first swalming. 'I'his is alway's the cause of their first swarming, unless the stock liad lost their Queen previous to swarming, in whicl casc, the colony assune the condition of a hive that has once swarmed, and may come out before the hive is full of comb or becs.

The old Quecn gocs out with the nev colony, and lcares the remaining stock without a hoad, (or femalc.) But nature has supplicd them with the instinct, and they commonly have the means of repairing the loss, which a ncwv colony, unaccompanicd by a Queen, could not obtain. They liare the lares or grub of the common worker, and the powser to convert it to a Queen. They soon discover their loss, and immediately set themsclves to work to fill the vacancy, in constructing several rojal cclls into which they remove the young grubs which 
would have become workcrs, and by fecding them on royal jelly, in a few days they have a Quecn. The eggs are commonly laid in litters, about three times a weck, during the brceding-season; and the becs, to be more surc of succecding in their experiments, divide themselves into squadrons, and undertulic to makc more than onc, by taking them from different litters, and also avoid the confusion of having a number of Qucens hatch at the same timc. This fact accounts for hoaring more than one Qucen at the same time. Two Queens cannot cxist together long in the same hive. Nature has implanted an implacable hatred betwixt them, and as soon as the nutes of the first-liatched Qucen are heard, they are answered by tones of defiance by the nymph Qucen younger, which is yet in her cell, and has not scen the light ; and if not prevented by the workers, her elder sister tears her from her cell, and immolates lice to her love of undisputed sway. But if the bees should be sufficiently numerous to protect their Quecn of their own making, for whom, as the work of their own hands, they secm to lave a blind 
attachment, the elder Queen colleets her followers, sallies forth, and seeks a new habitation. This is the eause of second and third swarmings which take place, and which frequently so weaken the live as to eause many of the evils to which bees are subjected, for which I think I have diseovered the remedy. See remarks on Rule 10.

If the second swarm does not come out before the 17th day, there is reason to believe that the Queen has disposed of all her competitors, and there will be no further swarming that season. The first Qucen is usually heard the 8th day after the first swarming.

I know of no rule by which the exact day of their first swarming ean be known with certainty. The apiarian will estimate near the time by the number of bees in and about the hive, as it will become very much erowded.

The day of second swarming, and all after that during the same season, may be most certainly predicted, as follows: Listen near the entrance of the hive in the evening. If a swarm is coming forth the next day, or in a short time, the Queen will be heard giving an alarm at 
short intervals. The same alarm may be heard until swarming takes place, or one Queen is destroyed by the other. The observer will generally hear two Qucens at a time in the same hive-the one much louder than the other. The one making the least noise, is yet in lier ecll, and in her minority.The sound emitted by the Qucens is peculiar, differing matcrially from that of any other bee. It consists of a number of monotonous notes in rapid succession, similar to those cmitted by the mud-wasp when working her mortar, and joining it to her cells, to raise niss-wasps. If, after all, the weather is unfarorable to their swarming several days while in this peculiar stage, they will not be likely to swarm again the same season.

Bees are very tenacious to preserve the lives of their sovereigns, particularly those of thcir own raising; and when they find they have more than one in the live, they will guard each so strong as to prevent, if possible, their coming within reach of each other. 'Mley being thus strongly guarded to prevent the fight, is unquestionably the eause of their giving the 
alarm, as described in the foregoing article.'The knowledge of the existence of another Quccn in the same hive, inspircs them witl the greatest uncasincss and rage; and when the oldest one finds herself defeated in gaining access to her compctitor, she sallies forth with as many as sce fit to follow her, and secks a new habitation.

Before the becs sally forth, they fill their sacks with honey, and some of them carry bread on their lcgs, which supplies their wants, till they have found a new residence, and laid the foundation of their cells. In a very crowded state of the live, many becs are sometimes compelled to lic out before the Quecn leaves, and in the confusion of swarming, not being apprised of her intention to depart, leave without filling their sacks, and this is one cause of the irritability they manifest. 'I'his difficulty is obviated in the Vermont Hive. The drawers furnish them room for their labors till the Qucen and all her followcrs have finished their arrangements, and arc not compelled to leave cmpty-handed.

Another reason why becs are sometimes ir- 
ritable, and are disposed to sting when they swarm, is, the air is forbidding to them, by being cold, windy, damp, extremcly hot, or otherwise, so as to impede them in their dctcrmined cmigration. In all such cases, the apiarian should be furnished with a veil, made of millinet, or some light covering which may be thrown over his hat, and let down so low as to cover his face and boson, and fixal in such a manner as to prevent their stinging.Hc should also put on a pair of thick woolen gloves or stockings over his hands, thus managing thom without the least danger.

Experience and obscrvation have taught that the Queen lcaves the old stock first, and her colony rapidly follow. 'They fly about a few minutes, apparcntly in the greatest confusion, until the swarm is principally out of the hive. They then alight, generally on the limb of some trec, shrub or bush, or some other place convenicnt for them to cluster in a bunch not fur from the old stock, and malic their arrangements for a journey to a ncw habitation. Perhaps not one swam in a thousand lnow where they are going, until after they have 
left the old stock, alighted, and formed into a compact body, or cluster; and not then, until they have sent off an embassy to scarcl out a place for their future residence. Now, if the bees are hived immediately after they have alighted, before they send off their embassy to seck a new tenement, they will never fly away, admitting they have sufficjent room, (for it is want of room that makes them swarm in the first place, ) and their hive is clear of every thing that is offensive to them.

It is proper then that bees should be hived immediatcly afier lhey have elustered in a body. If this is not done before they have had time to send off an cmbassy to select a proper habitation, they should be immediately moved to the apiary, or to some place severul rods fiom the spot where they alighted, in order that they may not be found by their messengers at their return. That bees do send forth messengers to seck out a new residenec after they have swarmed, and clustered in a body, is cvident from the fact that manyswarms have becn known to enter and take up their abode where a few becs were scen a short 
time previous. They likewise have been known in frequent instances to remain over night, and even sevcral days and nights, before they left for the woods; and furthermore, when the bees go direct from the old stock, the bee-hunter takes their eoursc, by setting his compass, and fixing the old stock as his starting-point; for bees always take a direet and strnight course towards their new residenee, when they first start. Now if the hunter takes the old stock as his starting-point, in eonnexion with the plaee where the bees clustcred in a body, he will run as far from his hecs as east is from any other point of the coinpass.

Although bees have several thousand eyes, yet, they are fixed in their places in their head, like so many suns, and as they do not turn in their soekets, like the eyes of men and quad rupeds, they are unable to traverse a crooked path without extreme difieulty: and when their sight is entirely obstruetad for any length of time, they are compelled to alight.

When bees leave for a new residenee that is unknown to their owner, several miles distant, 
(and it is believed that bees even sce the tree they have selected for their residence, aniong many others, ) and if the wind blows so strong as to vary them from their course, if their observation is not inpeded, they will go direct to it : but if a hill intervenes so as to entirely obstruet their sight, they may be usually found elustcred in a body not far from the direet line, before they descend the hill on its opposite side. It is believed that the wind, in such cases, usually sags them out of thcir course; and although it may be but a few steps, yet the bees get so confused that they are compelled to re-organize before they can procecd on their journey.

Experience hes taught it is best to remove the new swarm to the place where it is intended to stand during the season, immediately after living. 'Ihey are creatures of habit, and very soon become associated with the objects and places about them; and if their hive and companions are not found in the usual place, they have no means of findir 'hem. More or less bees are lost by every rets val; and the longer they remain in the place where they are hived, the more will be lost when removed. 
No confusion or noise which is uncommon to the becs should ever be made during their swarming or hiving. 'The only cffect of noisc, ringing of bells, \&c., that $I$ could cver discover, was, to render them the more hostile and unmanagcable.

A clean hive is all that is necded for aswarm of becs, with careful and humanc treatment.

A cluster of bees should never be shook, or jarred any more than mercly to disengage them from the limb or place where they are collected, nor should they full any great distance, because their sacks are full when they swarm, which render them both clumsy and harmless, and harsh treatment makes them irritalble and unmanagrable.

When bees go from the old stock dircet to the woods, without alighting, it is when they lic out of the hive before swarming. It is bclicved that they, being clustered in a body on the outside of the hive, assume the organization of a regular :rm, and their embassy is sent forth to scar 1 out iu new residence before the swarm leaves the old stock. 'This difficulty is obviated in the Vermont Hive. In 
stcad of lying out before stvarming in idlencss as in the old box, they go up into the drawers, and are constantly cinployed in depositing the fruits of their labors, and arc less liable to organize in a body before swarming. It is indeed truc that bces lave bcen known to leave and go dircelly to the woods when they did not lic out before swarming. But, in all such cascs with which 1 am convcrsant, an attcmpt to swarming had been made previous, and the bees had returned to the old stock.

Becs become associated with the human family, and will not often flec to the woods, unless they arc neglected by their owner, or driven away by bad management. One of the principal causes of fugitive swarms is, want of vital air in the hive. 'L'he heat of the sun cxhansts the air in the hive of its vitulity in a few minutes, in a very lot day, and the bees arc compelled to leave it. In 15:38, many swarms were known to leave green trees where they were not well sharded by their own branches, and that of other trees. Special care should be exercised by the apiarian that the rays of thic sun are excluded from the 
bive. Animal licat in the hive is absolutely necessary to cnable the becs to make comb; but pent heat is fatal, both to the lives of the bees, and their worls. An umbrella should be held over the hive during hiving the bees in a hot day, unless it can be ollerwise shaded.

No ineonvenience will result from letting the bees into the drawers, in first hiving them, if the colony is so large that a majority of them cannot oceupy onc of them.

Becs commence making their comb where the largest proportion of the colony have sufficient room to work. Now, if a majority of the becs can get into one of the drawers, they will begin to make comb there, (for they always commence at the top and roork down, of course they will raise young becs and deposit bread in the drawer. If the swarm is so large as to be unable to work in the drawer, there is no danger of lcuing thon in; and yet, if the swarm is very large, there may be danger, if the bees are prevented from cntering the drawex, because they sometimes go off for want of room in the lower apartment. I therefore recommend letting the bees into the drawers at 
the time of hiving them, in all eases, except when the swarms are small-then, the rule should be strictly adheced to: notwithstanding I have hived hundreds of swarms for seventeen years last past, and have not lost a single swarm by flight to the woods, yet I hear of some losses of this kind, which render these remarks necessary. My practice in hiving is, to get the bees into the shade, hive them as soon as possible, hang on the bottom board, fisten the same forward by means of the button so as to prevent the escape of any of the bees except through the mouth of the hive, place the same immediatcly where I intend it to stand through the scason. Lot the bottom board down three cigit ths of an inch on the third diay after swarming, and turn the drawers four days after hiving, (unless they were turned at hiving.)

Occurrences have been hearl of where there would seem to have been viriations from the forcgoing rules concerning swarming, to wit: Bees have been known to swarm before the hive is full of becs or comb, and then, swarm again two or three dinys after. Now, 
there is reason to belicve that the old stock lost their Queen before swarming, and the bees assumed the condition of a hive that had once swarmed, and sent forth another to aroid the conflict of the Quecns. Very large colonics have been known to swarm out several bushels of bees under such circumstances.Variations from the common rules of making Quecns, more frequently oecur as follows, to wit: When the old Queen goes out with a swarm, she lcaves without providing more than one class of grubs, (larra, which are capable of being converted to Queens; and as the becs always make a plurality of them, they will all be of an age; and in the confusion of swarming, all that are hatched will sally out, and the hive left destitute of the means of repairing thcir loss. This accounts for sceing more than one Queen in some small swarms, or there may be more than one class of grubs in the hive after first swarming, and the bees make some Qucens from ench elass. Then more than one Quecn may be secn with a swarm; for all the Qucens leave, that are hatehed. The swarming season usually clos- 
0 in about seventcen days after its commencement, and the becs scem to possess a peculiar instinct in their naturc, which teaches them that the season is too far advanced ut this time for them to form new colonics with safcty; and thcy will not permit any of their Qucens to depart. I have observed, in repeated instances, very compact bunches of bees on the bottom board, some larger than a hen's egg, about the hour of swarming. On cxamining them, by separating off the becs in my hand, I always found the Queen in the centcr, unhurt, yet ncarly smothered. The bees will commit no violence upon her person, other than pilc on, and cluster around her in such a. manner as to exclude from her all the vital air, and she dies of suffocation.

\section{RU L E III.}

ON VENTILA'TING TIIE IIVE.

Graduate the bottom board and ventilator at pleasurc by mcans of the button or otherwise, so as to give them more or less air, as circumstances may requirc. 
REM A R KS.

Bccs requirc more air in order to cnable them to endurc the heat of summer and the sevcrity of winter, than at any other time. If they are kcpt out in the cold, they nocd as much air in the winter, as in the heat of summer. It is in a mild tempcrature only, that it is safe to kecp them from the pure air. If placed bclow frost in a dry sand-bank, they scem to nccd scarccly morc than is contained in their hive at the time they are buricd, during the whole wintcr. If kcpt in a clean, dry ccllar, the mouth so constructed as to liecp out mice, gives them enough. But if they are kept in the apiary, there should be a slow, imperceptiblc current of air constantly passing in at the bottom and off at the top through the ventilator, to let the cxcess of animal heat cscape in summer, and also to throw off the vapor caused by the breath and other exhalations of the bces, which causcs frost and ice in the hive in winter, and which is frequently the causc of the death of the bees. 


\section{R U L E IV.}

ON PREVENTING ROBBERIES.

At the moment it is observed that robbers are wilhin, or about the hive, raise the bottom board so near the edge of the hive as to prevent the ingress or cgress of the becs, and stop the mouth or conmon entrance and ventilator. At the same time, take carc that a small space on all sides of the hire be left open, so as to afford them all the air they need. Open the mouth only at evening to let out the robbers, and close early in the morning, before they rencrv their altack.

\section{R E M $A \mathrm{R}$.}

Bees have a peculiar propensity to rob cach other, and cvery precaution necessary to prevent it should be exereised by the cultivator. Families in the same apiary are more likely to engage in this unlawful enterprizc than any uthers, probably because they are located so near each other, and are more lilicly to learn their comparative strength. I never could discuver any intimacy between colonics of the same apiary, exeept when they stood on the samc bench; and then, all the social intcrcourse scems to subsist between the ncarcst neighbors only. 
Bces are not likely to engagc in warfaro and rob eaeh other, except in the spring and fall, and at other times in the season when food is not easily obtained from blossoms.

Becs do not often engage in robbery in the spring, unless it is in sueh hives as have had their combs brokien by frost or otherwise, so as to causc the lioney to drip down upon the bottom board. Mruch care should be exercised by the apiarian to sce that all sueh hives arc properly ventilated, and at the same time closed in sueh a manner as to prevent the contrance of robbers in the day time, until they have mended the brcach, so as to stop the honey from running.

Clear water should be given them cvery day, so long as they are kept in confinement. I have known many good stoeks to be lost in the spring by being robbed; and all for want of eare. Bees rob each other when they can find but little elsc to do; they will rob at any time whien frost has destroycd the flowers, or the weather is so cold as to prevent their collecting honey from them. Cold, chilly 
weather prevents flowers from yielding honey without frost.

Bees need but little air at any time when they rob; and yet moje is nccessary for them when confined by compulsory means, than otherwise. When deprived of their liberty, they soon become restless, and use their best efforts to make their way out of the hive;hence the importance of lèving a small space all around the bottom, to admit air and to prevent their melting down, or use a sereen bottom board, which is better.

\section{R U L E V.}

O.J EgUALIZING COLONIES.

Hive one swarm in the lower apartment of the hive; collect another swarm in a drawer, and insert the same in the chamber of the hive containing the first. Then if the swarms are small, collect another small swarm in another drawer, and insert the same in the chamber of the hive containing the first, by. the side of the second. In casc all the bees from either of the drawers, mingle and go 
below with the first swarm and leave the drawer cmpty, then it may be removed, and another small swarm added in the same manner.

REMARKS.

It is of prime importance to cvery bee cultivator, that all his colonics be made as nearly - cqual in numbers and strength, as possiblc.Every cxpericneed bee-master must be aware that small swarns are of but litile profit to their owner. Generally, in a ferw days after they are hived, they arc gone; -no one can trace their stcps; some suppose they have fled to the woods-others, that they were robbed: but after all, no one is able to give any satisfactory account of them. Some picces of eomb only are left, and perhaps myriads of worms and millers finish off the whlole. Then the moth is supposed to be their destroyer, but the true listory of the case is generally this:- The becs become diseouraged, or disheartencd, for want of numbers to eonstitute their colony, abandon their tenement, and join with their nearest neighbors, leaving their eombs to the merciless depredations of the moth. They are $3^{*}$ 
sometimes robbed by the adjoining hives, and then the moths finish or destroy what is left.

When bees are collected in clrawers for the purpose of equalizing colonics, by doubling, \&c., they should be permitted to stand until evening before they are united, it being a moro favorable time for them to become acquainted with cach other by degrees; and the scent of the bees in the lower apartment will entey through the apertures during the night so much that there is a greater degrec of sameness in the peculiar smell of the two colonies, which takes off their animosity, if they chance to have any.

Sccond swarms are gencrally about half as large as the first, and third swarms half as large as second ones.

Now if second swarms are doubled, so as to make them equal in number with the first, the owner avails himself of the advantage of a strong colony, which will not be likely to become disheartened for want of numbers, nor overcome by robbers from stronger colonies.

It is far less trouble, and less expense, for the bee-owner to equalize his colonies, than to 
prepare hives and drawers of different sizes to fit eolonies.

When eolonies and hives are made as near alike as possible, many evils are avoided, and many advantages realized: every hive will fit a place in the apiary-every drawer a hive, and every bottom board and slide may in any case be used without mistakes.

Swarms may be doubled at any time before they become so loeated as to resume their former hostility, which will not be discovered bcfore they form a rational eharaeter and acquire rights of property. Bees are provided with a reservoir, or sack, to earry their provision in; and when they swarm, they go loaded with provision suited to their emergeney, which takes off all their hostility towards each other; and until these saeks are emptied, they are not easily vexed, and as they are compclled to build eombs before they can empty them, their eontents are ro tained several days. I have doubled, at a fortnight's interval in swarming, with entire suceess. The operation should be perform ad within two or three days-at the farthesi 
four days. The sooncr it is done, the less hazardous is the experiment.

As a general rule, sceond swarms only should be doubled. Third and fourth swarms should always have their Qucens talicn from them, and the bees returned to the parent stock, according to Rule 10.

\section{RULE VI.}

\section{ON REMOVING ILONEY.}

Insert a slide under the drawer, so far as to cut off all communication between the lower apartment and the drawer. Insert another slide between the first slide and the drawer. Now draw out the box containing the honey, with the slide that is next to it.Set the drawer on its window end, a little distance from the apiary, and remove the slide. Now supply the place of the drawer, thus removed, with an empty one, and draw the first inserted slide.

\section{REMARKS.}

Care must be exereised in performing this operation. 'The apertures through the floor in the chamber must be licpt closed by tl:e 
slides during the process, so as to liecp the becs from rushing up into the chamber when the box is drawn out. The operator must lilicwisc sce that the entrances into the drawer arc liept covered with tho slide, in such a mamer as to prevent the cscape of any of the becs, unlcss he is willing to be stung by them. If the bees are permitled to enter the chamber in very warm wcather, they will bc likely to hold the occupancy of it, and build comb there, which will change the hive into one no better than an old fashioned box.

I have succecded best in cxpelling the bees from the drawer, by the following method, to wit:- Shut the windorvblinds so as to darken one of the rooms in the dwelling-housc-raisc up onc easement of a window-then carry the drawer and place the same on atable, or stand, by the window, on its light, or glass end, with the apertures towards the light. Noxv remove she slide, and step immediatcly buck into the dark part of the room. The becs will soon learn their truc eondition, and will gradually loave the drawer, and return home to the 
parent stock; thus leaving the drawer and its contents for their owner; not however antil they have sucked cvery drop of running honcy, if there should chance to bc any, which is often the case, if their work is finished. Therc are two cascs in which the bces manifest some reluctance in leaving the drawer. The first is, when the combs arc in an unfinished state-some of the colls not scaled over.' The bces manifcst a great desire to remain there, probably to make thir storcs more sccurc from robbers, by affixing caps to the uncovered cells, to prevent the effluvia of running honcy, which is always the greastest temptation to robbers.

Bees manifest the greatest reluctance in leaving the drawer, when young broods are removed in it, which does not often occur, exccpt in such drawers as have been used for fecling in the winter or carly in the spring. When the Qucen has deposited eggs in all the empty cells belorv, she sometimes enters the drawers; and if empty cells arc found, she deposits cggs there also. In cillucr case, it is better to return the draverer, which will 
be made perfect by them in a few days. Bees never make honey, but extract it from such flowers and other substances as yield it without producing any change from its original state. Good honey is talien prineipally from white elover, orchards, sugar maplc, bass, and other forest trces, while in blossom. Poor honey is cxtracted from buckwheat, and low land flowers, hence, those who would sare their good honey unadulterated by that which is poor, will remove it before the latter can be extracted.

Spceial eare is necessary in storing drawers of honcy, when removed from the eare and protection of the becs, in order to preserve the holley from inseets, which are great lovers of it, particularly the ant. $\Lambda$ chest, made perfectly tight, is a good store-house.

If the loney in the drizwers is to be preserved for winter. use, it should be liept in a room so warm as not to free\%. Frost cracks the combs, and the honey will drip as soon as warm weother eommenecs. Drawers ehould be pecked with their apcritures up, for kecping or carrying to market. All itpiarians 
who would male the most profit fiom their bees, should rcmove the honcy as soon as the drawers arc filled, and supply their places with cmpty oncs. The becs will commence their labors in an empty box that has becn filled, sooner than any others. Drawers in old stocks, should be turned so as to let the -becs into them as carly in the spring as blossoms are scch.

\section{R UL E VII.}

TIIE METIIOD OF COMPELLING SIVARMS TO MAKE AND KEEP' EXTRA RUEEN'S FOIR 'TIIEIR APLARIAN, OR OWNER.

Take a drawer containing becs and brood comb, and place the sime in the chamber of an empty hive, take care to stop the entrance of the hive, and give them clean water, claily, three or four clays. Then unstop the moutli of the hive and give them liberty. 'The operator' must observe Rule 6 in using the slides, in removing the box from the original hive.

RFMA RKS.

'The prosperity of every colony depends entirely on the condition of the Quecn, when the scason is favoruble to them. 
Every bec-master should understand their nature in this respect, so as to cnable him to bc in readiness to supply them with another Queen when thej chenec to become destitute.

The discovery of the fuct, that bees have power to cliange the nature of the grub (larva) of a worker to that of a Quecn, is attributed to Bonner. But neither Bonner nor the indefatigable Huber, nor any other writer, to my knowledge, hak gone so far in the illustration of this discovery as to render it practicable and easy for common people to avail themsclves of its benefits.

The Vermont hive is the only one, to my knowledge, in which bees can be compelled to malic and lieep extra Quecns for the use of their owner, without extreme difficulty, as well as danger, by stings, in attempting the experiment.

The idea of raising her royal highness, and elevating and establishing her upon the throne of a colony, may, by some, be deemed altogetlier visionury and fitille; but I will assure the reader, that it is casicr done than can be described. I havo both raised them, and 
supplicd destitute swarms repeatedly.When the drawer containing becs and brood comb is removed, the bees soon find themselves destitute of a female, and immediately set themsclves to work in constructing one or more royal cclls. When completed, which is commonly within forty-eight hours, they remove a grub (larra) from the workcr's cell, place the same in the new-made Qucen's ccll, fced it on that lind of food which is designed only for Qucens, and in from cight to sixtecn days they have a perfect Queen.

As soon as the bees lave safely deposited the grulb in the new-made royal cell, the bees may have their libcrty. Their attaehment to their young brood, and thcir fidclity to thcir Quccn, in any stage of its minority, is such, that thcy will never leave nor forsake them, and will continue all their ordinary labors, with as much regularity as if thcy had a perfect Quecn.

In making Queens in small boxcs or drawers, the owner will not be troubled by their swarming the same scason they are made.Therc arc so fow bees in the dratwer, they are 
unable to guard the nymph Queens, if there are any, from bcing destroycd by the oldest, or the onc which cscapes from her cell first.

In cxamining the drawer, in which I raised an cxtra Queen, I found not only the Queen, but two royal eells, onc of which was in perfect shape; the other was mutilated, probably by the queen which came out first. Now when there are few bees to guard the nymphs, it would not be very difficult for the oldest Queen to gain access to the cells, and destroy all the minor queens in the drawer.

When a drawer is removed to an empty hive, for the purpose of obtaining an extra Queen, it should be placed some distance from the apiary, the bettcr to prevent its beingrobbed by other swarms. When it is some distance from other colonics, they are not so likely to learn its comparative strength.There is but little danger however, of its being robbed, until after the becs arc out of danger of losing their Queen, which gencrally occurs in the swarming scason.

The Queen is sometimes lost, when she goes forth with a swarm, in conscquence of 
bcing hearily laden with eggs, and too fecble to fly with her young colony; in which caso the becs return to tlicir parent stock in a fow minutes. In fact all occurrences of this kind originate in the inability of the Quecn. If she returns to the old stock, the swarm usually comes out again the next day, if the weather is farorable. If the Qucen is too fceble to return, and the apiarian neglects to look her up, and restore her to her colony again, (which he ought to do,) the bees will not swarm again until they liave made another, or arc supplicd, which may be done immediately by giring them any spare Qucen.

The Queen is sometimes lost, in consequenec of the young brood being too far advanced at the time of the departure of the old Quecn with her swarm. She may become barren or discased, and dic of old age, and all the grubs (larre) may have adranced so far towards the perfect Hy at the time of her dcath, that their nature could not be changed to a Quecn before the bees had be'come apprised of her true condition, or she may be lost at sccond swarming, as cxplained 
in remarks on Rule $2 \mathrm{~d}$, or she may be lost by aecident when she goes out of the hive into the air for exercise, or for the purposc of forming the sexual union with the drone; because, on returning to the hive, she has been known to enter her neighbor's hive by mistake, and lose her life before she could make her escape.

Note.-I think all close' obscrvers of bees will accord with this doetrine, when they reflect upon the faet that the Quecn frequently eallies forth for exereise or for other purposes, of which we sec repeated indieations duxing the breeding season, to wit: the bees assume the appearanco of the commeneement of swarming : they fly very thick before the hive, and run in every direction on its outside. In short, it would seem that hostilitics had eommenced in great carnest betwixt that and some unlinown hive, or that they were in a real sport. Now the bees miss their sovereign when these peculiar feuts are seen, and on her return, all is quict. 


\section{RULE VIII.}

ON SUPPLYING SIVARMS DESTITUTE OF A QUEEN, WITH ANO'IHER.

Take the drawer from the live, which was placed thcre according to Rule \%, and inscrt the same into the chamber of the hive to be supplied; obscrving Rule 6 in the use of the slides;-or remove a box containing brood comb as above described, and the bees will make onc for themselves;-or take a Qucen from any small swarm, and introduce her at the moutll of the hive.

\section{REMARKS.}

Colonics destitute of a Qucen may be supplied with another the moment it is found they have nonc; which is linown only by their actions.

Bees, when deprived of their female sovereign, ceasc thcir labors; no polcn or becbread is scen on their legs; no ambition scems to actuate their movements; no dead becs are drawn out; no deformed bees, in the various stages of their minority, are extracted, and dragged out of their cells, and dropped down about the hive, as is usual among all licalthy and prosperous colonies. 
Colonies that have lost their Queen, when standing on the bench by the side of other swarms, will run or fly into the adjoining hive without the least resistance. They will commenec their emigration by rumning in confused platoons of hundreds, from their labitation to the next adjoining live. They immediately wheel about and run home again, and thus continue, sometimes for several days, in the greatest eonfusion, constantly replenishing their neighbor's hive, by cnlarging their colony, and at the same time redueing their own, until there is not a single occupant left; and re. markable as it is, they leave every particle of their stores for their orvner or the depredittions of the motl.

Colonies lose their Queens more frequently during the swarning seison than any other.

In the summer of 1830 , I lost three good stockis of bees in consequence of their losing their Queens, one of which was lost soon after the first swarning-the two olhers not many days after the sceond sivarming-all of which manifested similar actions, and ended in the same results, which are more particu4. 
larly explained in remarks on Rules 2 and $\%$ - The Quecn, when lost in swarming, is easily found, unless the wind is so strong as to have blown her a considerable distance. A few bees are always found with her, which probably serve as her aids, and greatly assist the apiarian in spying leer out. She is frequently found ncar the ground, on a spire of grass, the fence, or any place most convenient for her to alight, when her strength fiils her. I once had quite a scarch for her majesty, without much apparcent success. At the same time there were flying about me a dozen or more common workers. At last her royal highnoss was discovered, concealed from my observation in a fold of my shirt-slceve. I then returned her to her colony, which had already found their way hoine to their parent stock.

'The Quecn may be tiken in the hand without danger, for she never stings by design; her timidity disarms her of every species of hostility; she may be drawn in quarters, and she will not sting. In trỳing many experiments I never could discover in licr, the least 
Lostile feeling, exeept when conflieting with one of her own species: her only cxertion seems to be, to make her escape; and ret she has a sting much longer than a worker.

The Queen is lnown by her peculiar shape, size, and movements. She differs but little in color from n worker, and lias the same number of legs and wings. She is much larger and longer than any of the bees. Her abdomen is very large and perfectly round, and is shaped more like the sugar-loaf, which makés her known to the observer the moment she is scen. Iter wings and proboseis are short. Her movements are stately and majestic; at the same time shy, and rather inclined to conceal herself from human observation; with sceming jealousy of being canght. I lave known her to remain in the air on the wing scveral minutes after her whole colony were alighted when I stood near the swarm. She is mucle less in size after the scison for breeding is over. Sle is casily sclected from among a swarm, at any scason of the year, by any one who has often seen her. Cut off the limb and sliake the bees on a table to find the Queen. 


\section{RUI,E IX.}

ON MUT.TIPLYING COLONIES TQ ANY DESIRABLE liX'ILNT, WI'LIOU'T 'THEIR SWALMING.

The large drawer, No. 1, should always be used for this purpose. Insert slides, as in Rule 6 , and remove the drawer containing bees and brood-comb, place the same in the chanber of an empty hive, stop the entranecs of both the new and old hives, taking care to give them air, as in Rulc 4. Give clean witer daily, three or four days. Now let the bees, in both hives, have their liberty.

R EMARKS.

This operation is botli pricticable and casy, and is of prime importance to all eultivators, who wish to avoid the necessity of hiving them when they swarm; and yet it will not prevent sivurming, except in that part of the divided colony which contains the Quecn at the time of their separation. 'The other' part being compelled to make another Queen, (and they generally make (wo or more) may swarm to avoid their conflict, as explitined in remarks on Rulc 2. The hive containing the old Quecn may swarm for want of room; but, at any rate, in performing the operation, it lias 
saved the tromble of hiving one swarm, and prevented all danger of their flight to the woods.

Multiplying colonies by this rule is a perfectly safe method of managing bees.

\section{R U I E X.}

ON PRRVENTING TIE DFPRLDATIONS OF TILE MOTH.

All such stocks as are infested with the moth, will manifest it as soon as warm weither conmences in the spring, by dropping some of the worns upon the bottom boutd. Let the apiarian clean off the bottom hoard every other morning; at the same time strew on is spoon full or two of fresh, pulverized salt.

Immediatcly after a sceond swarm has come forth from a hive, the same scason, the old stock should be cxamined; and if swarming lias redueed their numbers so low as to leave unoceupied combs, the apiarian should take the Qucens from the swam, and let them return to the old stock.

'Third and fourth swarms should always liave their Queens taken from them and the bices returned to the parent stock. 


\section{REMARKS.}

"This insect (the moth) is a native of Europe; but has found its way into this country, and naturalized itself here."-Thatcher.

'I'his unwelcome visitor has interested the attention and called forth all the cucrgies of the most experienecd apiarians of our couniry, and of many of the greatest naturalists in the world. Their novements lave been observed and scrutinized by the most learned - their nature las been studicd; vaious experiments have been tried to prevent their depredittions; but afier all, the monster in gaudy bue marehes onward, committing the greatest havoc and devastation, with but little molestation. I have lost my whole stock at least four times since 1803, as I supposed by the moth. I tried all the cxperiments recommended in this and other countries, that came to my lnowledge; but after all, I could not prevent their rarages.

In 1830, I constructed a live (which was patented in 1836) which I supposed would afford all the fucilities for managing bees in cvery manner that their nature would admit 
of, and at the same time render their cultivation most profitable to their owner. By constructing windows of glass, on every side of the hive, nearly the size of its sides, and darkening them by elosing doors on the outside of the windows, which may be opened at pleasure, I have been able to discover many important facts, both in relation to the nature and cconomy of the bee, and its encmy the moth; but, probably, much yet remains to be learned concerning both.

The moth, when first discovered by the conmmon obscrver, is a white worm or maggot, with a redish crusted lread, and varies in size according to its living. 'I'hose which have full and unmolested access to the contents of a hive, will frequently grow as large as a turkey-quill, and an inch and a half in length. Others are scarcely an inch in length when full grown. They have sixtcen short legs, and taper each way from the centre of their bodics.

'I'he worms, like the silk-worm, wind themselves into a cocoon, and pass the dormant (clirysalis) state of their existence, and in a 
few days come out of their silken cases perfect winged insects or millors, and are soon rcady to deposit their cgggs, from which another crop will be raised.

'I'he miller, or perfect moth, is of a grayish color, from thrce-fourths of an inch to an inch in length. 'They usually lie perfectly still in the day time, with their head downwaxds, lurking in and about the apiary. They cnter the hive in the night, and deposit their cgggs in such places as arc uncorcred-of . course unguarded by the becs. Thicse eggs hatch in a short time, varying according to circuinstances, probably fiom two or threc days to four or five months. At an carly stage of their cxistence, while yet a small worm, they spin a web, and construct a sillen shroud, or fortress, in which they cnvelope themsclves, and form a sort of path, or gillery, as they pass onward in thcir march; at thę same time being perfectly secure from the bees, in their sillien case, which they widen as they grow larger, with an opening in their front only, ncar thcir head, they commit the grcatest havoc and devastation on the ceggs, 
young bees, and all that come in thcir way as thcy pass.

When the moth has arrived to his full state of maturity, he malies preparation to clange to a millcr, by winding into a cocoon, as lias been already explainct. 'l'he miller is surprisingly quiek in all its morements, cxeecding by far the agility of the quickest bee, either in flight or on its legs. IIence the enemy bcconcs so formidable that the becs' are casily overcome, and soon fall a sure prey 10 him.

Now, in order to remedy the evils of the motlis, and prevent their ravages, and at the same. time aid the bees in their prosperity, and make them profitalble to their owner, I found it necessary to usc a live differing marerially from the old box, and conmenced 'operations in the one alrealy referred to, (called the Vermont Ifive, in a course of experiments which have produced results perfectly satisfactory. From 9 scasons c $x-$ perience in its use, I have not the lcast doubt that bees may be managed to the best adrantage, and without ever being materially injured by the moths. 
A bec-hive should be made in a perfectly workmanlilie manner, so as to have no open joints; the boards should be free from shalies and cracks, because the bees will make their tenement perfectly tight, so as to exclude light and air, by plastcring up all such places as are left open by the workman, with a lind of mortar, or glue, of their own make, which is neither honey nor wax, but is very eongenial to the growth of worms in the first stages of their larva state, and bcing secured from the bees by the timber, in a short time they are able to defend themselves by a silken shroud.

Now the miller enters the hive and makes an incision into the bee-gluc, or ceinent, with her sting, and leaves her eggs. These eggs hatch there, and the hrood subsist on the glue until they have arrived so far towards maturity as to enable them to encase themselves in a silken shroud; and then they move onward.

Now, unless the bees chance to eateh him by the collar, or nape of his neek, whilc fecding, and drag him out of his place of conceal- 
ment, they will be compelled to cut away the combs all around his silken path, or gallery and drug out the worm and his fortress all together. At the same time, the bees are compelled to cut away the combs so far as to destroy many of their young brooks in making room to remove the annoyance. I have known then to eut away their combs from fonr to eight or ten inches to remove this silken shroud, and have known them to eut and drag, out their only remaining Ruces before slie was transformed to the perfect fly, which occasioned the cntire loșs of the whole colony.

Repeated experiments lave demonstrated the fact, that placing bees on the ground, or high in the air, is no sccurity against the moths. - I have lost some of my best stocks by placing them on the ground, when those on the bench were not injured by them. I lave made a groove in the bottom board, much wider than the thickness of the boarts to the hive, and filled the same with loam. I then placed the hive on the same, in such a manner as to prevent any erack or vacancy 
for the worms; and yet in raising the live four weelis afterwards, I found them appirently full grown all around the live in the dirt. I lave found them very plentiful in a tree nincty feet from the ground.

The best method, in common praetice, to prevent the depredations of the inothe, is, to suspend the bottom board so fir below the lower edge of the live as to give the bees free entrance and egress all around the same during the motle seison, or to ritise the common hive, by plaeing under it little bloclss at each corner, which produees good eflect. But I know of but one rule, which is an infinllible one, to prevent their depredations, ind that is this: keep the eombs well guarded by loes. See Rule 10, and remarks on 12.

Large hives that never swarm, are never destroyed by the motl, unless they lose their Queen, melt down, or meet witl some easualty, out of the ordinary eourse of managing them. 'I'hey are not often in the least annoy"ed by them, unless there are bad joints, craclis, or shakes, so as to aftord some lurling places for the worms. The reason for their prosper- 
ous condition is obvious. The stock of becs are so numerous that their combs are all kcpt woll guarded during the moth scason, so that no miller cau enter and deposit her eggs.

Hives made so small as to swarm, arc liablo to reduce their colonics so small as to lcave combs unguarded, especially when they swarm three or four times the same scason. All swarms, after the first, sally forth to avoid the battle of the Qucens; constantly making a greater draft, in proportion to the number lefi, until the combs are partly exposed, which gives the miller free accoss to their edges.The sceds of rapine and plunder are thus quickly sown, and soon vegetate, and fortify themselves by their sillen fortress, before the bees are aware that their fronticrs arc invaded. Whilc the moths are thus engaged in cstablishing their posts on the fionticrs of the bees, the latter are constantly and indefatigably engaged in providing themselves with another Queen, to supply the place of the old one, which has departed with a swarm, and raising young bees to replenish their reduced colony. Now as the motlis have got possession of the 
sround on their frontiers, it requires a tremendous cffort on the part of the bees to save their little colony from a completc overthiow.

If late, or second and third swarms are always returned immediately, according to the rule, the combs are kept so guarded that the moths are compelled to kecp their distince, or be stung to death beforc they can accomplish their purposes.

Hives made so large as not to swarm may lose their Queen, and then they will abandon their habitation and emigrute into the adjoining hivc, leaving all thcir stores to their owner, which, unless immediately taken care of, the moths will not fail to destroy.

The moths are often complained of when they are not guilty. Hives are frequently abandoned by their occupants, in conscquence of the loss of their Quecn, unnoticed by any observer, and before anything is known of their fate, the hive is destitute of bees, and filled with moths.

In the summer of 1834 , one of my neighbors had a very large hive that never swarmed, which lest their quecn; and in the course 
of a fow days the bees entirely vaeated their tcnement, and emigrated into an adjoining hive, leaving the whole of their stores, which amounted to $215 \mathrm{lbs}$. of lioney in the comb. No young bees or moths were discovered in the hive. Instanees of this kind frequently occur, and the true cause is unknown, from inattention.

The Quecn is much more tenacious of life than any other bee, and may live mueh long cr. It is believed that the eommon bees do not often live to cxeced 18 monthș. The Queen is supposed to live several years. By elipping one wing of a Queen aceompanying a seeond swarm, she has been known to eome out with the first swarms for several suecessive years. But one Queen cxists in the sume hive any great length of time. When therc are more than one, the pceuliar sound of each, as cxplained in remarks on Rule 2, is heard by the other, which usually results in a battle between them, or the issue of a swarm in the eourse of a day or two, unless the swarming season is ncarly at a elose, then, the eomnion becs sometimes smother 
them as explained in remarlis on IRule 2.

Bees, when placed in a darli room in the upper part of thic lousc, or some out-housc, are easily kept (not cultivated) a while, and may be of some benefit to their owner; but as they are liable to most of the casualties tlat swarming lives are, they cannot be as profitable. It takes screral years before mucli comfort, otlier than the amusement of seeing them work, can be realized; besides, if they chance to escape the moth, the combs are rendered exceeding dark colored and filthy where the bees locate in the winter; and a disagrecable smell, which is causcd by their winter breath and other cxhaltations, is the result. In a fow years the bees acquire habits of indolenec, and as a natural consequence, soon manifest it by their irritability, unlike those colonies which are industrious and in a healliy and prosperous condition.

Large colonics never increase their stock in proportion to the swarming colonics. 'There is but one female in a large colony, and they can do but little morc in raising young bees than to kecp their stock good by replenishing 
them as fast as they dic off or are destroyed by the bircls, reptiles and insects, which are great admirers of them, and sometimes swallow them by dozens. Now if it requires five swarming colonies to be cqual in number to the one first described, it is not difficult to imagine that five times as many bees may be raiscd by the swarming colonies: for one Quecn will probably lay as many cggs as another.

The swarming hives are no more liable to be destroyed by the moth, during the swarming season, than others, if the hives are kepo well replenished with bees aceording to Rulc 10.

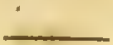 \\ R U L E XI. \\ ON FEEIHNG BEES.}

If it is found that a swarm uced fecling, hitch on the feeder, well stored with good honey, while the weather is warm in October; or place comb filled with strained honey in the cliamber of the hive, or on the bottom board, or both at the same time, without 
dripping, - and the bees will store the honey in the lower apartment of the live, if done while the weather is varm.

The apiarian should use the same precaution in fccding, as directed in Rulc 4 , to prevent robberies.

REMARKS.

The best time to feed is in the fall, before cold weather conmenees. All hives should be weighed, and the weight marked on the hive before becs are hived in them. Then, by weighing a stock as soon as frost has killed the blossoms in the fall, the apiarian will be able to form a just estimatc of their neecssities. When bees are fod in the fall, they will carry up and deposit their food in such a manner as will be convenient for thera in the winter.

If feeding is neglected until cold weather, the bees must be removed to a warm room, or dry cellar, and then they will carry up their food, generally, no faster than they consume it.

$\Lambda$ feeder should be made like a box with five sides closed, lcaving a part of the sixth side open, to admit the bees from their eomunon entrance rvith its Loor level, when bitch- 
ed on the front of the hive. It should be of sufficient deptls to lay in broad comb, filled with honey. If strained honey without combs is used for fecding, a float, perforated with many holes, should be laid orer the whole of the honcy in the box, or feeder, so as to prevent any of the bees from drowning; and at the same time, this float should be so thin as to cnable them to reach the honcy. It should be made so small that it will scttle down as fast as the honey is removed by the bees.There should be a tubc inserted rertically through the float and made fast to it, extending upward through the top of the box in such a manner as to receive the honey" from a tunnel and convey the same directly under the float. A light of gliss should be placed in the back side, and a door to close and darken it at pleasure.

Great profits may be made in large apiarics by foeding cheap honcy in the fill. The bees; being compelled to carry up and deposit the cheap honey in the lower apartment of the hive, (and they will live on that as well as any other,) their owner can compel 5 * 
them to carry as mucli purc whitc clover honey into the drawers the following scason, there being no room to store it below.Swarms will feed out and deposit ten pounds of honey a day and night, each hive. Small dravers cannot be depended on as fecters, except in the spring and summer, unless they are licpt so varm that the vapor of the becs will not frecze in them. It would be cxtremely liazarclous for the bees to cnlcr a frosty drawer. They will sooner starve than attempt the experiment. Drawers may be used without danger from robbers, but when the fecder is used, robbers must be guarded agninst as dirceted in Rule 4.

Bees should not be fed in the spring unless they are nearly destitute of honey, because they fill up the brood comb too much with honey: when fully fed in the fitll, the bees store up the loney in such a manner as will be convenient for them in the winter, and notwithstanding the cells for raising young bees are filled up with honey at that time, the bees consume the honcy and emply the breeding cells in the course of the winter, so 
that the Quecn is not interrupted in depositing her eggs to raisc young bees in the spring following.

A good swarm of bees in the Vermont Hive should wcigh at least 25 pounds the 1 st of December, in addition to the weight of the hive.

Carc shonld be cxercised, in fall-fceding, to supply them with good honey, otherwise the colony may be lost before spring by discasc. Poor lioncy may be given them in the - spring, at the time when they can obtain and provide thenselves with medicine, which they only best understand.

Sugar dissolved, or molasses, may be used in the spring to some advantage; but ought not to be substituted for honcy, when it can be obtaincd.

\section{RULE XII.}

ON WINTERING BEES.

Turn over the drawers so as to prevent the entrance of the bees, or their breath, in Scptember or fore part of October. When cold 
weather commences, suspend the bottom board hall an inch, and open the ventilator.

\section{REMARlis.}

The watery substance which is caused by the breath and other cxhalqations of the becs, and collects in the dravers in cold weather; should be licpt out of them; because frost forms in them, and runs down through tho apertures on to the bees as often as it melts, and makes the bees damp and the combs mould; besides, this vapor penetrates and fills the timber (drawers and chmber) and causcs a disagrecable smell the following scason, and is the cause of introducing the little ants into the cliamber.

'There are three principal causes of death among bees in the winter, to wit: want of honey, (not bread, for they never tat it except when in the larva statc) want of air, and ficezing.

Becs sometimes die of starvation, with plenty of honey in the live at the same time. In cold weather they crowel togetlicr ins a small compass in order to kecp warm; and then, their 1reatl, and vapor collect in frost 
in all parts of the hive, exeept in the region they oeeupy. Now, unless the weather moderates, so as to thaw the iee, the bees will be compelled to remain where they are loeated until their stores are all consumed that are within their reach. One winter we had eold weather ninety-four days in sueeession, during which time the bees eould not move from one part of the hive to another. I examined all my hives on the eighty-third day, and on the ninetieth day I found four swarms dead. I immediately examined for the eause, which was as already stated. I then earried all iny hives into a warm room and thawed them, so that the bees could move.

Too muel swarming frequently oeeasions the loss of the old stoek the winter following, beeause their eompanions are so reclueed in numbers that the necessary animal heat ean not be' liept up in the hive to prevent them from perishing by eold. All sueh stocks should be stored in a dry eellar or some varm room, where they can be kept comfortable during cold weather. It is believed that bees may bo liept through the winter without los- 
ing them, if the apiarian is attentive to their wants. If destitute of honey, he will feed them.-If suffering for want of air, (which is the most frequent causc of dcath,) he will ventilate them.- If freezing, he will thaw them out. In short, if they are apparently dead, he will resuscitate anil bring them to life and aetivity, whieh may be done in all eases (exeept when smothered) if attended to in season. In February 1838, I had a sivarm that were starved by design. I resuscitated them three times without feeding in three successive days before life was extinct. The life of bees many times is in a state of suspension considerable time before their death, and may be resuscitated by human aid, when otherwise life would become extinet. I have resuseitated them repeatedly under various eireumstanees for myself and neighbors. Some of the best stocks I now own were once apparcntly dead. A sereen bottom board should be used so as to let up the warm air into the hive, and at the same time enable the apiarian to control and keep the bees in the hive during the proeess 
of resuscitation. The fecler should be used in every case, to give the bees cxereise, and restore activity.

A cellar made in the side of a dry hill, so covered as to lieep out water, is a good storage for wintering bees. There slould be two ventilators at the two most extreme parts of the cellar-one near the bottom and on its side, to admit pure air-the other through the top or covering, to let the bad air eseape.

\section{R ULE XII.}

ON TRANSFERRING SWARMS.

This operation should never be effected by compulsion.

Finst Metuod.-Insert drawer $\mathbb{N}_{\mathrm{O}} \mathrm{O} 1$ into the chamber of the bive to be transferied, as early as the first of May. If the bees fill the drawer, they will recede from the lorrer apartment and winter in the drawer. As early in the spring as the bees carry in bread plentifully on their legs, remove the drawer, which will contain the principal part of the bees, to an empty hive. Now remove the old hive a few teet in front, and place the new one con- 
taining the drawer where the old one stood. Now tum the old live bottom up. If there are any bees left in the old live, they will soon return and take possession of their new habitation.

Second Metrod.-Talie drawer No. 1, well filled by any hive the same season-insert the same into the chamber of the hive to be transferred, in September, (August would be better.) It the bees need transferring, they will repair to the drawer and mako the same their winter quarters. 'I'hen proceed in the spring as directed in the first method.

REMARIS.

This management should exeite a decp interest in every eultivator, both in a temporal and moral point of view.-Temporal, becauso the lives of all the bees are preserved;moral, bceause we are aceountable to God for all our acts. We are not to be justificd in taking the lives of animals or inseets, which are but leint bicssingz, unless some benefit to the owner can be derived from their death, whieh will outweigh the cvils resulting from such a sacrifice. Duty compels me to protest in the strongest terins and feelings against 
the inhuman practice of taking the lives of the most industrious and comforting insects to the wants of the human family by fire and brimstone.

When bees have oceupied one tenement for several ycars, the combs become thick and filthy, by being filled up with old bread and cocoons, made by young bees when transformed fiom a larva to the perfect fly.

Bees alvays wind themselves in their cells, in a silken cocoon, or shroud, to pass their torpid and defenecless (shrysalis) statc. These cocoons are very thin, and are never removed by the becs. 'They are always elcaned immediately after the escape of the young bees, and others are raised in the same cells. 'Ihus a number of bees are raised, which leaves an additional cocoon as offen as the transformation of one succereds that of another, which often occurs in the course of thic season. Now in the course of a few years the cells become eo contracted, in consequence of locing thus filled up, thit the bees cone forth but mera dwarfs, and cane to swarm. Combs are rendered uscless by being filled up with old bread, 
which is never used execpt for fecling young bees. A greatcr quantity of this breat is stored up yearly than is uscal by them, and in a few ycurs they have but little room to perform their ordinary labors. Hence the necessity of transforting them, or the inhuman sentenec of death must be passed upon them, not by being hung by the neck until they are : dead, but by being tortured to death by fure and brimstonc.

It is obvious to cvery cultivator that old stocks should be transferred. I have repeatedly transferred them in the most approved manner, by means of an apparatus constructed for that purposc; but the operation always resulted in the loss of the colony aficrwards, or a swarm which would have come from them.

When it is necessary to transfer a swarm from one Vermont Hive to another of the same kind, insert drawer No. 1 into their chamber in the spring, say the lirst of May. If they fill the dritwer, let it remain there; if they need to be chimged to a new hive, they will recede from the lower aprarment and 
make the drawer their winter quarters, which should remain until warm weather has so far advaneed as to afford them bread. Then they may be removed to an empty hive, as directed in the Rule. Now the drawer contains no bread, and should remain in the old stock until the bees can provicle themselves with a sufficiont quantily of that article to feed their young bees with; for bread is not collected early enough and in sufficicnt quantitics to feed thcir young as much as nature requires. If the bees fail in filling the drawer, one should be used that is filled by anothcr swarm. Thus the aged and infirm stock is changed into the full vigor of youth by their own frec act, without any compulsion of their owner.

If bees are transferred from the old box hive, or from any other to the Vermont Ifive, execpt as deseribed in the forcgoing remarks, it should be done inmediately before, or forthwith aftex the second swarm has left the hive. Then, both old and young should be colonized together. If the operation is performed before first swarming, their owner will be sure to 
lose one swarm in the wanton destruction of eggs, larva and chrysalises, and if it is done after the first swarm lcaves, before a Queen is heard, he will get the bees without a Queen, becanse the old Qucen leaves the hive with the first swarm, and another is not usually hatched sooner than scren, eight, or nine days after first swarming: and if transforring is delayed until the swarming season is through, the bces will not malke a sufficient quantity of comb to cluster in; nor honey enough to sustain them through the following winter.

I would not be understood to approve of transferring from the old box until the combs are so old as to produce dwarfs. 


\section{GENERAL OBSERVATIONS.}

The reader might have expected many things demonstrated in this work, which are omitted by design.

The strueture of the worlier is too well understood by cvery owner of bees to need is particular deseription. So also of the drone; and the Queen has already been sufficiently described to enable any one to select her out from among her subjects. If any further description is desired, the observer can casily alisfy himself by the use of a microseope. Every swarm of bees is composed of three classes or sorts, lo wit: one Queen or female, drones or males, and neuters or workers.The Queen is the only female in the hive, and lays all the eggs from which all the young bees are raised to replenish their colony. Sho possesses no authority over them, other than that of influence, which is derived from tho fact that she is the mother of all the bees, and they; being endowed with instinetive knowledge of the fact that they are wholly 
dependent on her to propagate their species, treat her wilh the greatest lindness, tenderncss and revercnce, and manifest at all times the most sincerc attachment to her by fecding and guarling her from all danger.

The government of a hive is nearer republican than any other, because it is administered in cxact accordance with their nature. It is their peculiar natural instinct, which prompts them in all their actions. The Qucen has no more to do with the government of the hive than the other becs, unless influcnec may be called government. It is found by experiment that bees will go to work, and continue Lhcir labors witlı perfect regularity, with a dead Queen, as long as she is confined in the hive in such a manner that the becs will kecp ler in motion; but as she is the only female in the hive, no cggs will be laid, no brood comb made, and no young bees raised: notwithistanding there is a plenty of drones, as there are no grubs (larva) in the hive to consume the polen, the combs will be unusually loaded with bread; and the bees will finally perish by the depredations 
of the motlis, or want of animal heat in the winter, which is generated in the hive by a populous community only. If any one is disposed to doubt on this subject, let the experiment be tricd ivith skill, and I will be answerable for the result, to wit: Take the Qucen from a first swarm (sccond swarms frequently have more than onc Qucen,) lill her, and by means of a fine wire, or strong string, suspend her in the hive; now let in the swarm; confine the bees in the hive until they have found their sovcreign, and clustered about her; then give the bees liberiy to work. If the experiment ends here, entire loss will be the final result. Bces linve so many admirers, they will soon dwindle away in numbers, and perish in eonsequenee of losing so many of their companions, which are caught by the birds, and are lost by other casualties, uriless they have the means of propagating their species. But there is a remedy by which the bees may be supplied with a Queen, whielı is more simple, though rnore difficult than the ordinary inculiod. T'ake brood comb containing eggs and larva of 
workers only, from any hive that contains them; place the same in a drawer in its natural position; now insert the drawer into the chamber of the hive, so that the bees can have access to them and they will have a Queen in a ferv days. If she finds empty cells in the hive, during the brecding season. she will deposit cggs there, because it is he: nature to do so; and the nature of the workcrs prompts them to take care and nurse all the young larva, labor and collect food for thcir sustenance, guard and protect thcir habitations, and do and perform all things in ducobedienec, not to the commands of the Quecn, but to thcir own peculiar instinet.

The drone is probably the mulc bce, notwithstanding the scxual union has never been witnessed by any man; yot so many cxperiments have becn tricd, and obscrvations made, that but litte doubt ean be cntertained of it truth. 'That the scxual intercourse takes place high in the air, is highly probable from the fact that I lave seen an attcmpt at copulation by the drone with the Quecn on their return from an cxcursion in tho air, before 
she could enter the hire, and other inscets of the fly tribe do copulate in the air, when on the wing, as I have 1epeatedly scen. 'That the drone is the malc bec, is probable from the fact that the drones are not all killed at once; but at least onc in each live is permitted to live several months after the geyeral massacrc.

I examined four swarms, whose colonics were strong and numerous, three montlis after the gencral massacre of the drones, and in threc hives I found one drone each; the other was probably orerlooked, as the bees were thrown into the firc as fast as they were cxamined. But there are many mysterious things concerning them, and nuch might bc written, to little purpose; and as it is designed to go no further in illustrations than is nccessary to aid the apiarian in good management, many little speculations have been entircly omitted in the work, and the reader is referred to the writings of Thatcher, Bonner, and Huber, who are the most voluminous and cxtensive writers on bees within my hnowledge. 
The importance of taking the Queens from all small, and late swarms, and returning them. to the original stock, cannot be too much insisted upon. It constitutes a very important feature in my system of managing becs. Even first swarms that arc late, had better be compelled to remain in the parent hive. The prosperity of a hive of becs depends in a great degrec upon their number being kept full.They are-their own best defonders. 'Their number not only protects them from the depredations of the moth and the robberies of other swarms strongcr, but the aninal hcat which is generatcd in the hive by a populous community protccts the combs from molding, and the bccs from freezing in the coldest wcather. But the apiarian derives another advantage by keeping his hives full of becs; he sccures a larger quantity of honey from a full swarm, than from many small ones. The time for making much honcy docs not usually last morc than 20 or 30 days in Vcrmont, and the greatest proportion of honey that is deposited in the live for winter usc is collected in fiftecn or twenty days. This renders 
it very importunt that the attention of the old stock should not be called off from gathering honcy at this time, to guard their hive from the attaclis of moths to which it is left cxposed, by the descution of that part of their body which has accompanied the Queen to constitute a new strarm. Hives that are well stocked with bees in the spring, swarin much earlicr than fecblc oncs, and are able to use the best of the season to great advantage.

In speaking of the adrantiges of a large colony, I would not be understood to approve of the plan of tho:se person: who so far depart from the cconomy of uature as to raise bees in a chamber, or in ally way where their colonics will much excecd fiftcen or sixteen quarts of becs.

Bees are creatures of habit, and the cxercisc of caution in managing the m is sequired. A stock of becs shovild be placed where they are to stand through the season before they form habits of location, which will talie place soon after they commonce tlecir labors in the epring. 'They lcurn their lome hy the oojects surrounding them in the immed late ricinity of 
the hivc. Moving them, (unless they are carried beyond their knowled ge, ) is often fatal to them. 'Thıe old bees forget their new location, and on their returu, when collecting stores, they laze about where they formerly stood, and perish. I have known some finc stoclis ruined by moving them six feet, and from that to a mile and a half. It is better to move them before swarming than afterwards. The old becs only will be lost. As the young oncs are constantly hatching, theil habits will bc formcd at the new stand, and the combs will not bc as likcly to bccounc vacated, so as to afford oppertunity to the moths to óccupy any part of their ground.

Sivarms, when first hived, may be moved at plcasure without loss of bees, admitting they are all in the hive; their habits will be formed in exact proportion to their labors.The first bec that cmpties his sack and goes forth in scarch of food, is the one whose liabits are first established. I have observed many becs to cluster near the place whero the hive stood, but a ferv hours after hiving, and perish. Now if the swarm had been 
placed in the apiary, immediately after they were hived, the number of bees found there would have becn less.

Becs may be moved at plcasurc at any season of the year, if they are carried several milcs, so as to be beyond their knowledge of country. They may le carricd long journeys by travelling nights only, and affording them. opportunity to labor and collect food in the day timc.

The importance of this part of bec-management is the only apology I can make for dwelling so long on this point. I have known many to suffer scrious losses in consequence of moving their becs after they werc well settled in their liabor's.

Bees should never be irritated, under any pretence whatever. 'They should be treated with attention ancl lindness. They should be kept undisturbed by cattle and all other annoyanecs, so that they may be approaclied at any time with safety.

An apiary should be so situated, that swarming inay be observed, and at the same time where the bces can obtain food easily, 
and in the greatest abundance. A bec-house should be so constructed as to sccurc the hives perfectly from the rays of the sun, and wcather. All the light the bees can have* about the hive is necessary, to induce them to swarm carly in the scason, and a plenty of good air (not air cxhausted of its vilality,) is absolutely necessary to promote their health, prevent them from acpuiring habits of indolence, and hostile feelings, at the sanc time, a strong current of air, in the inmediate region of the hive, near the entrance, where the bees aliglit, must be avoided: 'otherwisc, when the bees slack up their specd, to alight, the wind will blow them so far from the live, that many of them fall, and perish.

Nuch depends on the construction of the housc, as wcll as the hivc. It has been a general practice to front bec-houses either to the cast or south. This doctrine slould be cxploded with all other whins. Apiarics should be so situated as to be collvenient to their owncr; as mucl as any other buildings. I have them front towards all the cardinal points, but can distinguish no difference in their prosperity. 
Youngswarms should be scattered as much as convenient during the summer scason, at least eight fect apart. If they are not housed, they should be sot in a frame, and so covered as to exelude the sun and weather from the hive. As a fencral rule, bees flourish better in vallics than on the ligh lills contiguous to thcm, on account of bcaring thcir burtlicns home will greater ease, descending, than ascending, with a heavy lond.

It is not surprising that this branch of rural economy, in consequence of the depredations of the moth, is so much negglected. Notwithstanding, in some parts of our country, the business of managing bees has becn cntirely abandoncel for ycars, I am confident they may be cultivated in such it manner as to render them more profitable to their owners than any branch of agriculture, in proportion to the capital necessary to be invested in their stock. They are not taxable property, ncither does it require a large land investment, nor fences: neither does it require the owner to labor through the summer to support them through the winter. Care is, indecd, necessary; but $\mathrm{s}$ 
child, or supcranuuated person can perform most of the duties of an apiarian. Thie cobwebs must be kept away firm the immediate vicinity of the hive, and all other annoyances removed.

The management of bees is a delightul employment, and may be pursued with the best success in cities and villages, as well as towns and country. It is a souree of great amuscment, as woll as comfort and profit.They collect honey and bread from most kinds of forest trees, as well as garden flowers, orchards, forcsts, and ficlds;-all contribute to their wants, and their owner is gratified with a taste of the whole. Swect mignonette cannot be too highly recommended. This plant is easily cultivated by drills in the garden, and is one of the finest and richcst llowers in the world from which the honcy-bec cau extract its food.

The Vermont Hive is the only one I can use to much advantagre or profit. In the summer of 1831,1 received in swarms and extra honey from iny best stock, thirty dollars; and from my poorost, fiftecu dollars. My early 
swarms afforded cxtra honey which was sold, amounting to from five to ton dollars cach hive; and all my latc sivarms which were doubled, stored a sufficicnt quantity of food to supply them through the following winter. The rules in the foregoing work, perhaps, may be decmed, in some instances, too particular; yct, in all cases, thcy will be found to be safe and unfailing in thcir application, though liable to exceptions, such as are incident to all spccific rules. 
Every lec-owner should be able to answer the following questions in the refirmative, if the wislics to make his bees profitable:

Have you weighed and marked the weight on all your hives before using them?

page 66

Have you scratched the under side of the chamber floor?

Did you secure the hive from the rays of the sun at the time of hiving the bees?

26

Did you let the bees into the drawers at the time of hiving all your large. swarms?

27

Did you close the hive, and move it as directed?

Have you let down the bottom board, and turned the drawers as directed?. 28 Have you removed your honcy before buckwheat is in blossom? 41

Have you tuken the Qucens from all your late swarms? 53-62-84-85 
Have you turned your diarvers so as to prevent the breath of the becs from entering them in Scptember?

$69-70$

Have you fed your destitute slocks in October?

66-67-65-69

Have you wcighed your stock hives, and is there at least $25 \mathrm{lbs}$. in addition to the weight of the hive on the first of Dec.? 69 Have you been particular to see that all your hives are properly ventilated, and the bees kept lively during cold weather? 71-72 Have you turned the drawers to all your stock hives, so that the bees can enter them as soon o.s blossoms are scen in the spring? 42 Have you visited your becs, and examined their true condition, two or three times in each rreek, through the whole year? 


\section{$\checkmark$. \\ A P P ENDIX.}

The Hiver is made of three rough boards, half inch thick, seven inches wide, eighteen inches long, nailed togetlicr like a common trough, open at both ends-a strap of iron riveted on its outside; across the centre of each board, with a shank or socket to inscrt a rod to handle it with, so that when inverted by means of the rod, and placed over the becs when alighting, forms a kind of half-hive, which they readily cnter. 'There should be from a dozen to twenty half-inch lroles bored through the top board, so as to let the alighting bees enter through the lioles. When a small proportion of the bees are found in the. liver, it may be moved a few fect from the limb, which may be shaken with another rod with a hook on its end, which disengages the bees, and in a few moments the whole swarm will be found in the hiver. By the addition of ferules and joints, the hiver may be raised to any reasonablo height. Thus the labor of 
climbing, the use of ladders, and cutting the limbs of precious fruit-tyees, is entirely dispensed with. It likewisc cnables the apiarian in large cstablishments to divide out and keep separate his swarms, which might otherwise alight many in one body.

But another method of collecting and hiving swarms, is recommended by some good bcc-managers, which is of prime importance whon the experiment succecls. It is this :Takc any common rough board, fourtecn inches or more in widtl, twelve fect or more in length, let one end of the board rest on the live that is to swarm-say half the distanco from the mouth or commou entrance to the top-the other end on the ground. When swarming talics place, the becs will usually be found clustered in a body on the underside of the board, not far from the old stock.Any one will know how to turn the board over, and place an empty hive over the becs. Becs, when swarming in this way, will bo less likely to be scen, and thercfore may flec to the woods unloss assiduously watched. The live should likewise be sccured from the rays of the sun. See page 20. 


\section{N D $\mathrm{E}$.}

Paro.

Ifule I. On the Construction of the Five, 5 Kulc IT. On Swarming and Hiving, Rulc 1IT. On Vontilatin

Rule IV. On Pruventing Robbcries, . Rule V. On Equaliziny Colonies, by doubling, troblirg, Erc., • • $\mathbf{3 4}$ Fulc VI. On liemoving Iloncy, : 38 Rule VII. The rethod of coinfellin; Swarms io malse extra Quens, 7nd lecp then for the wie of Rulc VIll. On supplying Swarms with Rulc VIll. On supplying Swarms with Quecns, when neciossiary, 14 30 32 Fule IX... On muliph, ins Colonics to arsy desirubla cstent, tviihout. swarming,

- Rulc X. On proventing the depredatinns of the Mioth,

Fuic Xi. On Feeding, Pulc NIT. On Wintering,

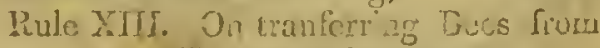
one Irive to aut? XIV. (ieneral Obsprvations, . XV. Queslions to Bes-owners, . XVI. Appendis, . . . .

48

52

53 65 65

73 79 03 94 


